\title{
GROUND WATER IN THE CITY OF VARANASI, INDIA: PRESENT STATUS AND PROSPECTS
}

\author{
Kshitij Mohan, Ajai Srivastava, Praveen Kumar Rai \\ Department of Geography, Banaras Hindu University, Varanasi, India
}

Manuscript received: June 1, 2011

Revised version: September 5, 2011

\begin{abstract}
Mohan K., SRivastava A., Rai P.K., 2011. Ground Water in the City of Varanasi, India: present status and prospects. Quaestiones Geographicae 30(3), Bogucki Wydawnictwo Naukowe, Poznań, pp. 47-60, 3 Figs., 8 Tabs. ISBN 978-83-62662-75-3. ISSN 0137-477X. DOI 10.2478/v10117-011-0026-9
\end{abstract}

ABSTRACT. The city of Varanasi is short of water. The city obtains a total of 270 million litres water from the river Ganga and tubewells. Yet every fifth citizen lacks drinking water. The ground water is polluted due to nitrate and faecal coliform. A further problem is the plan to settle the growing population in a new township nearby under the integrated development plan of Greater Varanasi, a part of the Jawajarlal Nehru Urban Renewal Mission. To fulfill the growing demand of fresh water, new water bearing horizon of the most affected part of the city i.e. southern part is to be identified. This paper reports a study of the variation in the grain size attributes of an aquifer material taken from different depths from the affected region in order to establish the generalized hydrological properties and recommend the depth of the well accordingly. From the grain size analysis and hydrological study it may be concluded that water bearing zones are mainly found in three horizons at the depths 44-56 m; 56-87 m; and 87-165 m. The third water bearing horizon (total thickness being $78 \mathrm{~m}$ ) can act as a good potential ground water horizon for a new township. Due to its greater depth, the water would be relatively fresh being characterized by very low concentration of dissolved solids. Therefore, this horizon is strongly recommended for utilizing the water resource for the township.

KEYwORDS: Ground water, aquifer sands, hydrological properties, Gangetic alluvium, Grain size parameters

Praveen Kumar Rai, Lecturer (PGDRS \& GIS), Department of Geography, Banaras Hindu University, Varanasi-221005, U.P., India, email: rai.vns82@gmail.com

\section{Introduction}

The City of Varanasi (Benaras, Benares) lies on a bend of river Ganga (Ganges), one of the largest rivers of the World. The city $\left(25^{\circ} 18^{\prime} \mathrm{N}\right.$ and $83^{\circ}$ $01^{\prime} \mathrm{E}$ ) is bound by the small rivers Varuna on the north and Assi on the south (Fig.1). Fig. 1 shows the map of the city of Varanasi municipal limit (dotted line) showing water supply zones (solid line), water ponds (shaded polygons) and some important locations referred to in the text.

Varanasi is short of water. The present water supply system is not enough to cater to around 1.6 million people in the city. There is a considerable gap between the recommended norm and the actual water supply.

The city obtains a total of 270 million liters water from the river Ganga and ground water 
source. Yet every fifth citizen lacks drinking water. The problem is bound to turn worse with the proposed plan to settle a new population in a new township nearby. Hence, there is an urgent need to search ground water bearing horizon. The water intake points from river Ganga are at two levels to suck water from the river and when the water level goes down below these two suction points, which quite often happens, the intake system fails to draw anymore water from the river. This is the reason why, there is dependence on ground water. Further, the existing intake and supply system being very old laid out with smaller diameter pipes for a population (figure not available) far less than the present population (16 lakhs according to 2001 Census), the pipes limit the intake of water. Here, a question might arise as to why old pipelines cannot be replaced or else why new pipelines cannot be laid. Most of the city surface below which the pipelines are laid, is built up and hence there is no scope to dig up to replace the old pipes. And, new pipeline to be laid out, the same built up space is a problem to dig and lay the new pipes. Some socioeconomic and political compulsions come in the way to dig and lay new pipelines in this built up space which is quite extensive and highly dense with houses. Surface pipelines cannot withstand the onslaught of indisciplined public especially in this part of India. This is the reason why, there is no other alternative but to go for ground water to compensate the scarcity of drinking water in the area of study.

\section{Current Status of water supply}

State government department, Varanasi Jal Sansthan is engaged in the supply of drinking water to the people residing in the city of Varanasi. This Jal Sansthan draws raw water from two sources: (a) the river Ganga and (b) ground water.

Bhadaini Intake Works is pumping a total of $1.25 \times 10^{5} \mathrm{~m}^{3} \mathrm{~d}^{-1}$ raw water of the river through its six pumps, four each with a capacity of $40 \mathrm{~m}^{3} \mathrm{~min}^{-1}$ and 2 each with $30 \mathrm{~m}^{3} \mathrm{~min}^{-1}$. The pumped raw water is sent to the Bhelupur Water Works, situated at about $1.5 \mathrm{~km}$ away from the water drawing point, for its chlorination and purification. The treated water is supplied to the inhabitants of the city through a network of pipelines the total length of which is about $575 \mathrm{~km}$. This water supply system was laid way back in 1892 by James Princep. Sometimes, because of failure of electricity supply the Bhadaini intake works fail to pump up water from the river to its full capacity and because of which the problem becomes acute. At a few places, quite often, public of the city raise a hue and cry about mix up of water with sewage because of leakage in the pipes. The some gastro-enteric diseases and other health hazards support this type of claim.

Along with the river water, a total of $1.45 \mathrm{~m}^{3} \mathrm{~d}^{-1}$ of ground water is extracted from 118 deep bore tube wells installed in different localities of the city to cater to the growing demand of potable water. Further, a total of 2,347 hand pumps were also set up at different parts of the city.

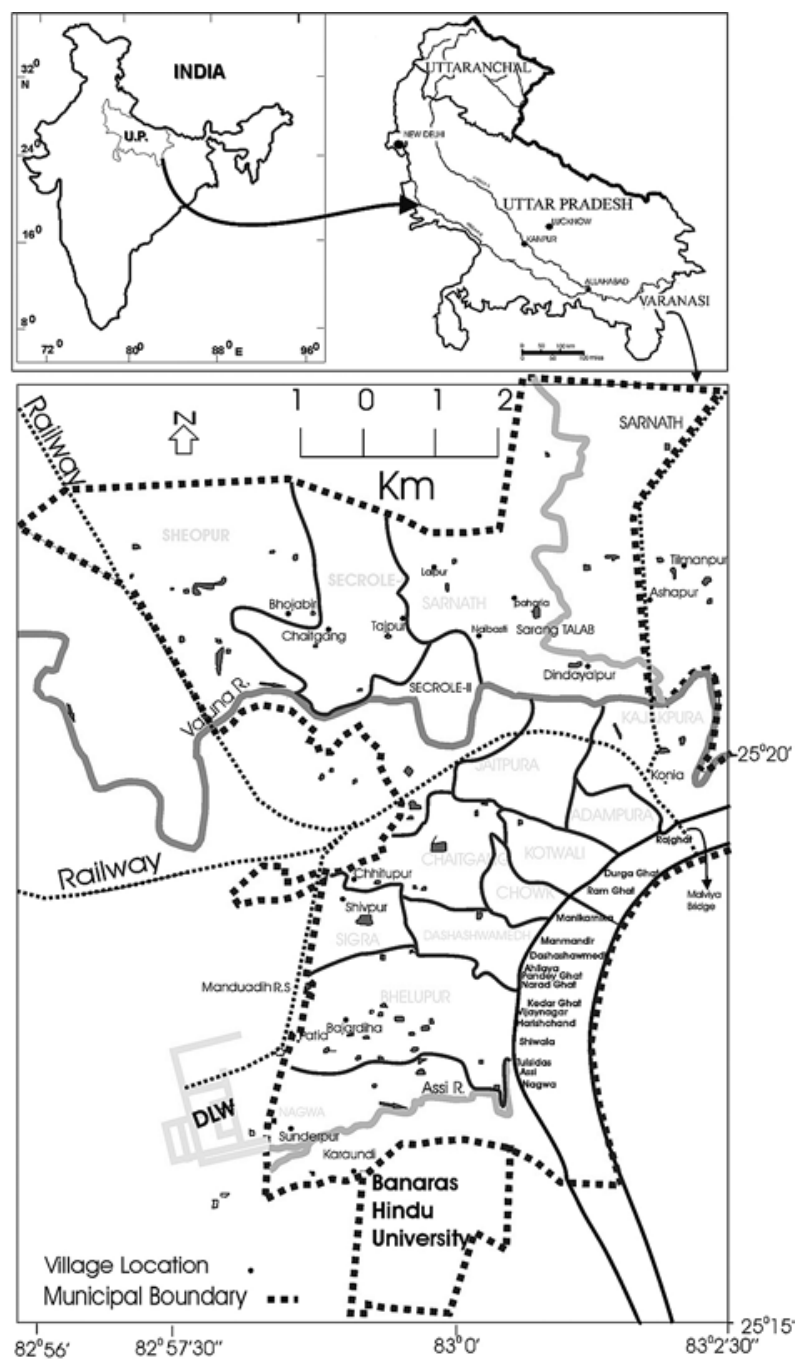

Fig. 1. Map of the city of Varanasi municipal limit. 
Jal Sansthan has divided the city area into 16 zones (11 zones within the city spread between Ganga and Varuna and 5 zones in the transVaruna area (located to the other side of the river Varuna, as a western extension of the city) for the management and distribution of water supply. The trans-Varuna is dependant entirely on ground water.

With all types of water supply put together, Jal Sansthan provides a total of $2.70 \times 10^{5} \mathrm{~m}^{3} \mathrm{~d}^{-1}$ water. With such a capacity of supply, each person in the city gets $169 \mathrm{~L} \mathrm{~d}^{-1}$ water, which is far below the, WHO's norm of $270 \mathrm{~L} \mathrm{~d}^{-1}$. That means, about one fifth of the population of the city is not supplied with potable water.

The river Ganga is an important source of drinking water in the city, but the level of water of goes down for various reasons, below the intake points. Jal Sansthan finds it very difficult to draw $1.25 \times 10^{5} \mathrm{~m}^{3} \mathrm{~d}^{-1}$ water not only during spring, winter but also during some period of rainy season. What, more there is problem of pollution concentration.

\section{Available resources}

The city, a part of Central Ganga Alluvial Plain, is underlain by the Quaternary Alluvium comprising fine to coarse grained sand, clay and clay with Kankar. The alluvium belongs to the Quaternary Group of Pleistocene System of the Recent geological age. To be precise, the Older Alluvium is Middle to Upper Pleistocene and the Newer Alluvium is recent (Krishnan 1960).

Study of the Upper $120 \mathrm{~m}$ of alluvium based on records of tube wells in the area indicates the presence of the two distinct sedimentary horizons, namely (i) back-swamp clays containing Kankar at places lying immediately below the land surface and having an average thickness of about $50 \mathrm{~m}$ and (ii) the underlying meander-belt deposits consisting of mixed populations ranging from fine to coarse sands, having an average thickness of about $60 \mathrm{~m}$. In these two unconsolidated alluvial horizons, ground water occurs in the pore spaces in the zone of saturation (Pathak 1977).

These two ground water bodies are hydraulically separated where the back swamp deposits are thick but are likely to be interconnected where they are comparatively thin. These two types considerably differ in their capacity to absorb water at the land surface and to transmit water to the zone of saturation. The back-swamp clays are generally dense and impervious and cover the entire area. These clays are massive and contain Kankar and thin lenses of fine-grained sands. Because this material is generally too fine grained to transmit water readily, it prevents the downward percolation of water from the land surface and also confines water in the underlying meander-belt sand deposits. These deposits constitute a ground water reservoir from which very large supplies of water can be recovered perennially for irrigation, municipal and industrial purposes. The shallow ground water in the back swamp deposits (clay and Kankar beds) is generally unconfined and its static water level is only a few metres below the ground level. It supplies water to a good number of dug wells, bore wells and wells fitted with small pumps used either for domestic or irrigation purposes. The meander belt sand deposits form the main ground water body in the area and supply water to a large number of tube wells used for irrigation, industrial and domestic purposes. The deep ground water body, considered to be hydraulically continuous, is known to be confined locally. The piezometric surface of the deep body varies and is generally known to be deeper in comparison to the static water level of shallow water body. It should be mentioned that the ground water table in the city has gone down to $4.6 \mathrm{~m}$ (15 feet) below the level it used to be earlier. The ground water level was at a general depth of $12 \mathrm{~m}$ to $18 \mathrm{~m}$ (40 to 60 feet) in the year 2005; whereas in the year 2006 it was between $17 \mathrm{~m}$ and $21 \mathrm{~m}$ (55 to 70 feet) deep (Report of the 'Hindustan' 1996).

As the texture and thickness of the meanderbelt deposits vary considerably, their water yielding capacity also differs from place to place. Most of the tube wells in the city derive water from meander-belt deposits. These tube wells yield ( 30 to 60) $\mathrm{L} \mathrm{s}^{-1}$ water. A few tube wells which derive water from the thin disconnected sand lenses in back-swamp clay yield less than $15 \mathrm{~L} \mathrm{~s}^{-1}$.

In 1999, the Municipal Corporation (now Nagar Nigam) made a survey and found 5000 wells in the city. But, a recent survey reported only 
2204 wells in existence. Obviously the rest of the wells were filled with wastes, garbage's etc.

\section{Ponds as a source of recharge}

The most important source to sustain ground water body, in fine to coarse-grained sands of the Older Alluvium, is rainfall that seeps down to the water table. Other sources include infiltration from river while in spate, return seepage from irrigation and inflow from neighboring areas. The area receives rainfall during south-west monsoon.

The annual average precipitation ( 50 years average) in the city is $1076 \mathrm{~mm}$. In the year 2008, the city witnessed a rainfall of only $300 \mathrm{~mm}$. There is no established system of ground water recharging in the city.

In Varanasi, there used to be many ponds and tanks dating back to ancient time. Besides serving as the holy places for holding Hindu religious rituals, they also played an important

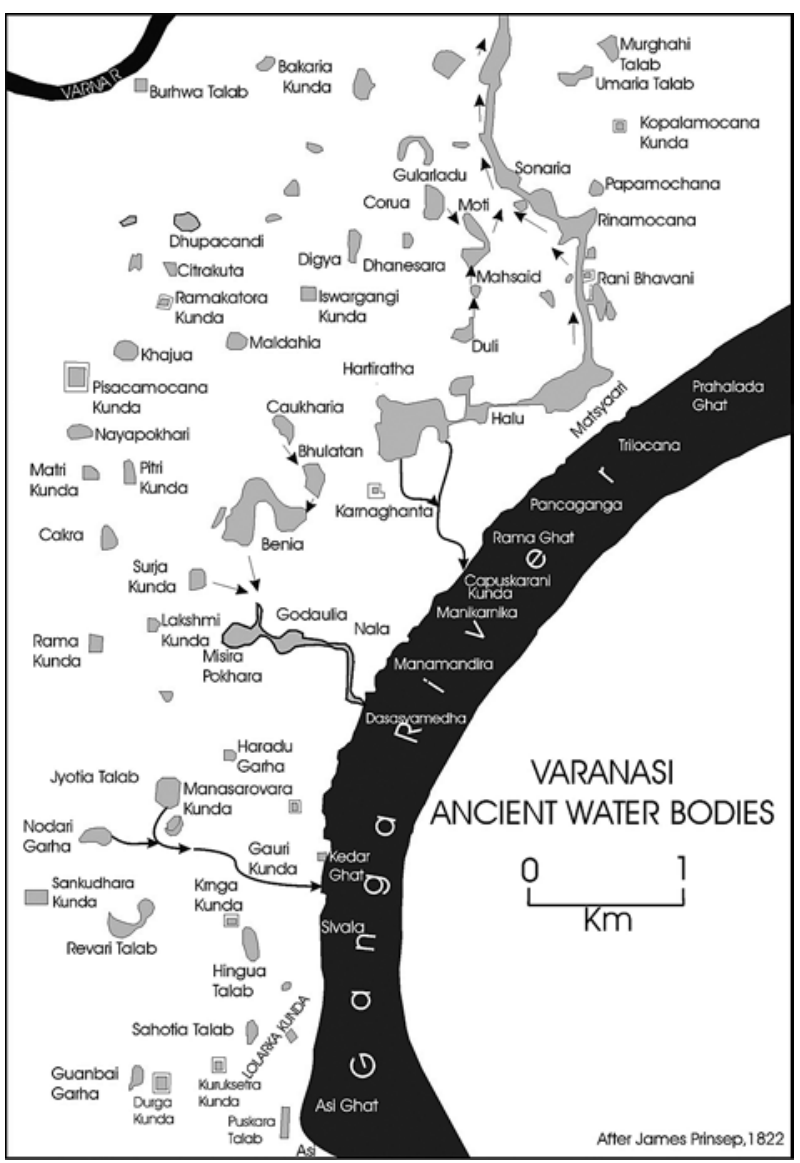

Fig. 2. Ancient water bodies of Varanasi. role in rainwater collection and thereby served as sources for ground water replenishment. Totally 118 ponds and tanks in the city, have been documented (Figs. 1 \& 2).

However, due to rapid expansion of the city, most of these sacred ponds have been wiped out from the map of the city. Our investigation has revealed that 44 ponds were replaced by settlements. This shows utter disregard of environmental conservation to accommodate growing population. Public unawareness of the importance of these ponds aggravated the situation by completely or partially filling up many of the existing ponds with garbage and wastes.

Fortunately at the behest of avid citizens and environmentalists, the city authorities have prepared a list of 54 ponds and tanks which in need of urgent rehabilitation; the plan has not been effectively implemented though. These 54 ponds may soon die out if immediate rehabilitation measures are not implemented. Only about half a dozen of them have water throughout the year. The Central Government has released a sum of Rs 16.9 million rupees for the maintenance and beautification of water bodies of Varanasi .

\section{Pollution}

Pollution of the ground water in the city is mainly sourced from heaps of garbage. The solid and liquid wastes generated out of the household and industrial activities are dumped and released in uncontrolled sites. On an average, 661 million tons of solid waste in a day is produced in the city, but only $87 \%$ of which is collected for ultimate disposal, and the rest is left uncollected. This is primarily due to lack of effective labor strength and fleet of vehicles for collection, transportation and disposal. These wastes are disposed of in the low lying areas of the city where the tanks and ponds are located, which were once important sources of ground water recharge in the city. In order to know the impact of wastes on ground water quality, water samples from 6 sites (hand pumps) around garbage dumps were analyzed. At two sites (Aurangabad and Badi Gaibi), samples were taken in two different (summer and rainy) seasons. and the results are listed in Table 1.The ground water from these two sites appears 
to be unremarkably affected by the solid waste dump in terms of chemical contents. However, the turbidity is far above acceptable limit, rather close to the maximum permissible limit. The hardness exceeds a value higher than double the acceptable limit but still below the permissible limit. Unexpectedly, the water is free of coliform.

The ground water in rainy season has slightly lower alkalinity, TDS, turbidity, chloride and conductivity but higher TSS, COD, and nitrate. The water from Aurangabad has higher TDS, hardness, COD, and $\mathrm{pH}$ and that from Badi Gaibi has higher alkalinity, chloride, sulphate, TSS and turbidity. These spatial differences might be the result of seepage from different garbage dumps.

During the last rainy season (July-August) water samples were taken from hand pumps surrounded by waste dumps on 4 sites keeping in view the likely impact of the dumps on the ground water quality. The parameters considered were again 14; the analysis was done in the laboratory of the U.P. Jal Nigam. The results obtained are shown in the Table 2. TDS is well above the acceptable limit though within permissible limit in ground water from 3 of the 4 sites studied. The color (except at Nagwa Police Chowki), taste/ odour (brackish) and $\mathrm{pH}$ are more or less normal. So are the calcium, magnesium and iron contents. Among the 4 sites, iron is conspicuous at Nagwa Police Chowki site.

Here the water is characterized by highest amount of turbidity (12 NTU) in all 6 sites but

is devoid of fluoride and nitrate. Ground water from Aurangabad and Badi Gaibi has higher chloride level than the water from the other 4 sites. Sulphate is highest at Beniabagh.

In the final analysis, only striking result is the presence of $\mathrm{NO}_{2}$, which is beyond the permissible limit at Pisachmochan site.

No doubt, there is a marked variation in the chemical parameters of water at different sites. In fact, the impact of solid waste dump, in general, is not beyond acceptable/permissible limit which may be attributed to the deep (more than 150 feet) drilling of hand pumps.

In the Ganga Action Plan Phase-I, the construction of municipal sewage treatment plants

Table 1. Quality of ground water in summer and rainy seasons.

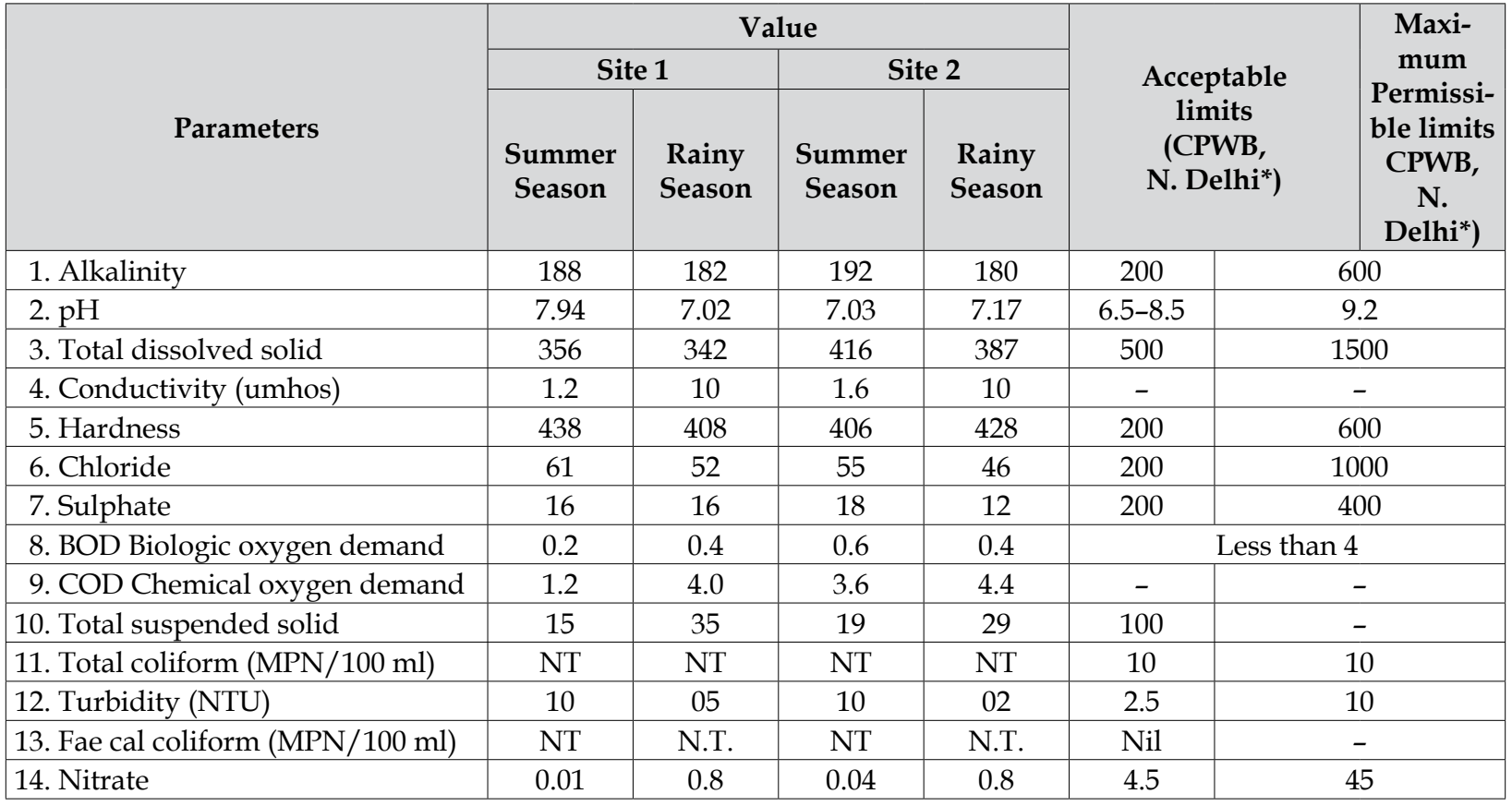

Note:

1. All the results are expressed in $\mathrm{mg} / \mathrm{l}$ except $\mathrm{pH}$.

2. N.T.: Not Traceable, NTU: Nephlometric Turbidity Units

3. The test has been done in the laboratory of U.P. Pollution Control Board,

4. Varanasi

5. The two sites selected were rather in the midst of waste dumps and its water are under use by the inhabitants for domestic purposes.

6. Site1: Aurangabad, Site 2: Badi Gaibi

*CPWB- Central Pollution Control Board, New Delhi. ADSORBS/3/1978-79 
Table 2. Quality of ground water from Site 3 Nakhighat, Site 4 Benia Bagh, Site 5 Pichasmochan and Site 6 Nagwa Police Chowki.

\begin{tabular}{|c|c|c|c|c|c|c|}
\hline \multirow[b]{2}{*}{ Parameters } & \multicolumn{4}{|c|}{ VVVVS } & \multirow{2}{*}{$\begin{array}{l}\text { Acceptable } \\
\text { limits } \\
\text { (CPWB, } \\
\text { N. Delhi*) }\end{array}$} & \multirow{2}{*}{$\begin{array}{c}\text { Maximum } \\
\text { Permissible } \\
\text { limits } \\
\text { (CPWB, } \\
\text { N. Delhi*) }\end{array}$} \\
\hline & Site 3 & Site 4 & Site5 & Site 6 & & \\
\hline 1. $\mathrm{pH}$ & 7.5 & 7.2 & 7.5 & 7.1 & $6.5-8.5$ & 9.2 \\
\hline 2. TDS & 316 & 648 & 624 & 600 & 500 & 1500 \\
\hline 3. Hardness & 172 & 152 & 160 & 164 & 200 & 600 \\
\hline 4. Chloride & 16 & 168 & 168 & 164 & 200 & 1000 \\
\hline 5. Sulphate & 5.0 & 90 & 50 & Nil & 200 & 400 \\
\hline 6. Floride & Nil & Nil & 0.8 & Nil & - & - \\
\hline 7. $\mathrm{NO}_{3}$ (Nitrate) & 5.0 & 20 & 25 & Nil & 4.5 & 45 \\
\hline 8. $\mathrm{NO}_{2}$ (Nitrite) & Nil & 0.01 & 0.15 & Nil & 0.1 & - \\
\hline 9. Calcium & 26 & 29 & 30 & 24 & - & - \\
\hline 10. Magnesium & 26 & 20 & 21 & 26 & - & - \\
\hline 11. Iron & 0.3 & 0.4 & 0.3 & 1.0 & - & - \\
\hline 12. Colour & $<5$ & $<5$ & $<5$ & 10 & - & - \\
\hline 13. Taste/Odour & Unobjectionable & Brackish & Brackish & Brackish & - & - \\
\hline 14. Turbidity & Nil & 1.2 & 3.6 & 12 & 2.5 & 10 \\
\hline
\end{tabular}

Note:

1. All the results are expressed in $\mathrm{mg} / \mathrm{L}$ except stated otherwise.

2. The test has been done in laboratory of U.P. Jal Nigam, Varanasi

3. The sites selected are in the midst of waste dump and its water is under use by the inhabitants for domestic purposes.

*CPWB-Central Pollution Control Board, New Delhi. ADSORBS/3/1978-79.

in various segments of the city area i.e. Konia-Dinapur (in the northern sector) and Bhagwanpur (in the southern sector) was taken up. The treated sewage water, being plant nutrient, is widely applied to irrigate crops in the tract within vicinity of treatment plants. Persistent leaching of the dissolved nitrate content of the liquid wastes downwards through the permeable irrigated soil to the top saturated aquifer horizon possibly induced enrichment of nitrate content in ground water of the city. Besides, poor sewerage and drainage facilities, leakage of human excreta from very old septic tanks, and application of nitrogenous fertilizer might have also contributed to nitrate enrichment in the ground water.

In total, pollution of ground water in the city is mainly from urban and industrial wastes. However, the use of chemical fertilizers and pesticides in agricultural fields in the surrounding sub-urban sectors for cultivation purposes has also augmented the problem. A large variety of chemicals are being used by farmers in the agricultural fields to eradicate various types of agricultural pests, including insects and other organism. These pesticides find their way to ground water through percolation. Research on pollution of ground water in other parts of India has been reported abundantly (Roychowdhury et al. 1999, Rahman et al. 2001, Ahmed et al. 2001, Chaudhary et al. 2001, Chakraborti et al. 2002, Chowdhary et al. 2002, Chakraborti et al. 2003, Mukherjee et al. 2003, Rahman et al. 2003, Chakraborti et al. 2004, Rahman et al. 2005a, Rahman et al. 2005b, Rahman et al. 2005c, Bhattacharya et al. 2005, Mukherjee et al. 2005, Ahmed et al. 2006), but that of Varanasi is scarce (Raha et al. 2003, Singh et al. 2006). Varanasi is popular in the Indo-Gangetic plain for the production of vegetables and fruits. Thus, there was a quite long history of use of fat accumulative, highly toxic banned cyclodiene organo-chlorine pesticides in the city for agricultural purposes and also to maintain public hygiene (Raha et al. 2003, Singh et al. 2006). The higher amounts of aldrine in the groundwater in rural areas appear to be related to its extensive use in plant protection of cereals, vegetables and fruits for the last few decades. The relative concentrations of cyclodiene organo-chlorine pesticides in ground water were in the following order: aldrine $>$ chlordane> dieldrine $>$ heptachlore and its epoxide. The study (Raha et al. 2003, Singh et al. 2006) indicated that the banned cyclodiene organo-chlorine pesticides 
so far analyzed both in the rural and urban areas have crossed the FAO/WHO limit of water quality and contamination of these cyclodiene pesticides is in alarming stage for human and livestock consumption and the possibility of their accumulation in food chain can not be ignored. The higher amount of aldrine in groundwater in urban area appeared to be related to its extensive use in house hold purpose and plant protection of vegetables in kitchen gardens as well as public health programs through local municipality (Raha et al. 2003, Singh et al. 2006). UNICEF reported the presence of 'arsenic in the ground water of southern parts of the city at a level up to $499 \mathrm{ppb}$ far beyond the limit (10 ppb) set by the WHO and Bureau of Indian Standard for the potable water. The joint investigation committee comprising the representatives of Chief Medical Officer, Nagar Nigam and Jal Sansthan analyzed the ground water in the city and claimed that $75 \%$ of the water supplied through tube wells was safe and the rest was unsuitable for drinking purpose, through a orthotolidine test on quantity of chlorine in the water. But, the National Institute of Communicable Disease (NICD) has rejected this type of test by stating that the test lacks scientific basis. Nagar Nigam does not carry out coliform test to measure E. coli organism. The ground water in the first and second strata is polluted from nitrate and faecal coliform organisms. Banaras Hindu University in the southern part of the city fulfills its demand of water from the third strata occurring at $200 \mathrm{~m}$ below ground level through deep bores. The Central Government has initiated a plan in 1986 namely 'Rajiv Gandhi National Drinking Water Mission' to provide safe drinking water. The Mission has been entrusted to analyze the samples of ground water with respect to the levels of iron, fluoride, nitrate and total dissolved solid (TDS). Unfortunately, under this mission not much could be implemented in the State of Uttar Pradesh due to apathy of the State Government.

Although crisis of water is prevalent in the whole city, the southern part is suffering more owing to lowering of ground water each year. Brij Enclave is a densely populated area of the southern part of the city.

Here, ground water table dropped by $2.13 \mathrm{~m}$ (7 feet) in 2006 from a level of $17.68 \mathrm{~m}$ (58 feet) in 2005.
Report of the State Ground water Department states that the ground water in the city of Varanasi is depleting at a rate of $23 \mathrm{~cm} / \mathrm{a}^{-1}$ (Report of the 'Hindustan' 2006). Lowering of ground water in the southern part is 9 times faster than the rest part of the city. The Central Government has recently asked State Governments to prepare an integrated development plan for a well planned township under the proposed 'Jawahar Lal Nehru Urban Renewal Mission', so that it might meet the demand of rapidly growing population for the next 25 years. The State Government has submitted its detailed feasibility report to the Central Government for integrated development of the proposed 'Greater Varanasi', which includes the southern part of Varanasi city also. Therefore, the southern part, the most affected part in terms of water supply, might be developed as a township under the Mission.

\section{Identification of new water bearing horizon in the southern part}

To find new water bearing horizon in the southern part of the city is a few representative samples of soil were collected from the boreholes at the different depths at Karaundi near Banaras Hindu University (Fig. 1). The depths of the samples range from $0-175 \mathrm{~m}$; the depths and tentative field names of samples are shown in Table 3. With the help of grain-size parameters of the samples collected, the generalized hydrologic properties of the aquifer was established for identifying the water bearing horizons of the area.

\section{Laboratory investigations and results}

The laboratory investigations of the samples collected involve the following steps:

- Determination of textural property of aquifer sands through grain size analysis.

- Identification of the hydrological properties of water bearing horizon with the help of standard graph of Klein.

The grain size analysis has been carried out by using ASTM (American Association of Testing Material) sieve set for the determination of 

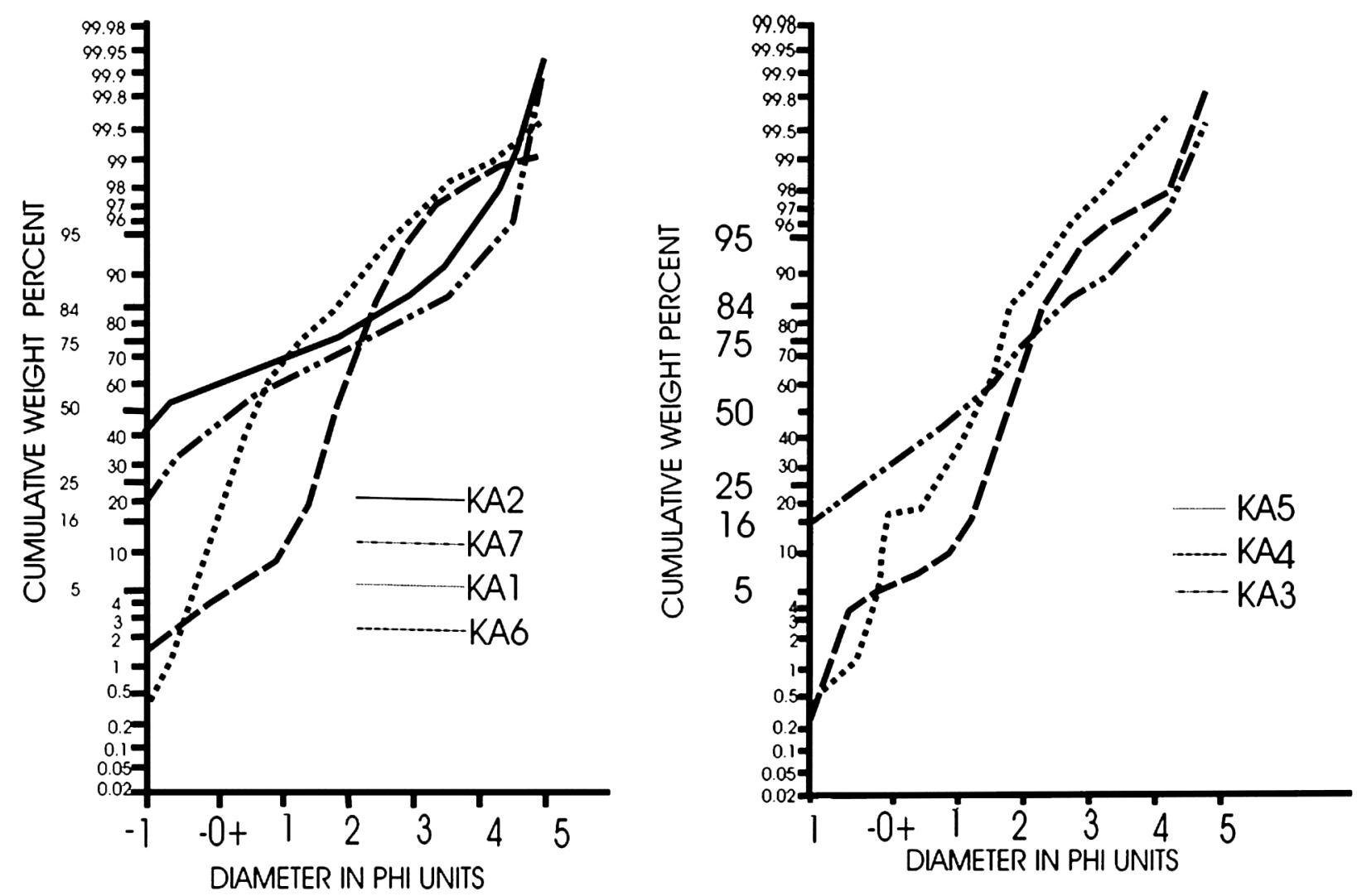

Fig. 3. Cumulative Curves of Aquifer Sands.

textural properties of aquifer sands. The results of sieve analysis are shown in the Tables 3 to 5 .

From the results obtained, cumulative curves (Fig. 3) were drawn and interpretation of the trend of the curves has been done. The study of frequency distribution pattern reveals that out of 7 samples, 5 are unimodal in distribution. In case of unimodal size distribution, the primary modes lie on $2.00 \varphi$ or $4.50 \varphi$. However, the mode shifts from $0.00 \varphi$ to $2.00 \varphi$ in case of bi modality. The cumulative plots have been made on logarithmic probability paper as the clastic material generally follows a logarithmic probability law. The nature of these curves establishes the relationship between the flow regime and grain size behavior as well as environmental interpretation. These curves (Fig. 3) have been studied on the basis of their morphology (Doeglas 1946, Sindowski 1957). The curves closely resemble with those of fluvial environment. The different percentile values deduced from the plots of curves have been given in the Table 8 which has been utilized for the determination of grain size (textural) parameters as shown in the same Table.
The grain size parameters - median, mean, standard deviation, skewness and kurtosis were computed as suggested by Folk \& Ward (1957). The formula used for calculations are given below:

$$
\begin{gathered}
\text { (Median) } \mathrm{Md} \varphi=50^{\text {th }} \text { percentile } \\
\text { (Mean Size) } \mathrm{Mz} \varphi=\frac{\varphi 16+\varphi 50+\varphi 84}{3} \\
\text { (Standard Deviation) } \varphi_{1}= \\
=\frac{\varphi 84-\varphi 16}{4}+\frac{\varphi 95-\varphi 5}{6.6} \\
\left(\text { Skewness) } \mathrm{Sk}_{1}=\right. \\
\frac{\varphi 84+\varphi 16-2 \varphi 50}{2(\varphi 84-\varphi 16)}+\frac{\varphi 95+\varphi 5-2 \varphi 50}{2(\varphi 95-\varphi 5)} \\
(\text { Kurtosis }) \mathrm{KG}=\frac{\varphi 95-\varphi 5}{2.44(\varphi 75-\varphi 25)}
\end{gathered}
$$

Median is a measure of central tendency, i.e. $5^{\text {th }}$ percentile. The Md $\varphi$ values for the aquifer sand range from $-0.50 \varphi$ to $1.90 \varphi$. The higher range of size variation is attributed to more fluctuation in a depositing medium. 
Table 3. Tentative field names, size grades and mass fraction of an aquifer sands.

\begin{tabular}{|c|c|c|c|c|}
\hline Sample No. & Depth (m) & $\begin{array}{l}\text { Field name of sam- } \\
\text { ples given tenta- } \\
\text { tively }\end{array}$ & Size grade & Mass fraction (\%) \\
\hline \multirow{6}{*}{ KA1 } & \multirow{6}{*}{0 to 30} & \multirow{6}{*}{ Very coarse sands } & Very coarse sands & 41.496 \\
\hline & & & Coarse sands & 17.749 \\
\hline & & & Medium sands & 10.267 \\
\hline & & & Fine sands & 9.545 \\
\hline & & & Very fine sands & 10.470 \\
\hline & & & Silt + Clay & 10.331 \\
\hline \multirow{6}{*}{ KA2 } & \multirow{6}{*}{30 to 40} & \multirow{6}{*}{ Very coarse sands } & Very coarse sands & 56.602 \\
\hline & & & Coarse sands & 9.905 \\
\hline & & & Medium sands & 6.977 \\
\hline & & & Fine sands & 10.154 \\
\hline & & & Very fine sands & 9.464 \\
\hline & & & Silt + Clay & 6.822 \\
\hline \multirow{6}{*}{ KA3 } & \multirow{6}{*}{40 to 44} & \multirow{6}{*}{ Very coarse sands } & Very coarse sands & 29.294 \\
\hline & & & Coarse sands & 14.686 \\
\hline & & & Medium sands & 25.711 \\
\hline & & & Fine sands & 16.348 \\
\hline & & & Very fine sands & 7.374 \\
\hline & & & Silt + clay & 6.219 \\
\hline \multirow{6}{*}{ KA4 } & \multirow{6}{*}{$44-56$} & \multirow{6}{*}{ Medium sands } & Very coarse sands & 5.056 \\
\hline & & & Coarse sands & 4.950 \\
\hline & & & Medium sands & 48.879 \\
\hline & & & Fine sands & 34.603 \\
\hline & & & Very fine sands & 4.111 \\
\hline & & & Silt + clay & 2.227 \\
\hline \multirow{6}{*}{ KA5 } & \multirow{6}{*}{$56-87$} & \multirow{6}{*}{ Medium sands } & Very coarse sands & 16.082 \\
\hline & & & Coarse sands & 16.111 \\
\hline & & & Medium sands & 48.729 \\
\hline & & & Fine sands & 15.510 \\
\hline & & & Very fine sands & 2.088 \\
\hline & & & Silt + Clay & 1.266 \\
\hline \multirow{6}{*}{ KA6 } & \multirow{6}{*}{$87-165$} & \multirow{6}{*}{ Coarse sands } & Very coarse sands & 14.894 \\
\hline & & & Coarse sands & 50.523 \\
\hline & & & Medium sands & 20.767 \\
\hline & & & Fine sands & 9.704 \\
\hline & & & Very fine sands & 2.556 \\
\hline & & & Silt + Clay & 1.185 \\
\hline \multirow{6}{*}{ KA7 } & \multirow{6}{*}{ 165-175 } & \multirow{6}{*}{ Medium sands } & Very coarse sands & 4.331 \\
\hline & & & Coarse sands & 4.615 \\
\hline & & & Medium sands & 48.057 \\
\hline & & & Fine sands & 37.501 \\
\hline & & & Very fine sands & 4.121 \\
\hline & & & Silt + Clay & 0.503 \\
\hline
\end{tabular}


Table 4. Grain size frequency distribution (weight percentage) of aquifer sands.

\begin{tabular}{|c|c|c|c|c|c|c|c|c|c|c|}
\hline \multirow{2}{*}{$\begin{array}{l}\text { Mesh } \\
\text { No. in } \\
\text { ASTM }\end{array}$} & \multicolumn{3}{|c|}{ Size in } & \multicolumn{7}{|c|}{ Sample No. } \\
\hline & \multicolumn{2}{|c|}{$\varphi$} & $\mathrm{mm}$ & KA1 & KA2 & KA3 & KA4 & KA5 & KA6 & KA7 \\
\hline 10 & -1.00 & \multirow{3}{*}{$\begin{array}{l}\text { Very } \\
\text { coarse } \\
\text { sand }\end{array}$} & 2.000 & 19.611 & 40.925 & 12.994 & 1.634 & 0.602 & 0.467 & 1.678 \\
\hline 14 & -0.50 & & 1.410 & 12.210 & 9.821 & 9.273 & 1.742 & 0.569 & 1.577 & 1.390 \\
\hline 18 & 0.00 & & 1.000 & 9.675 & 5.856 & 7.027 & 1.680 & 14.911 & 12.850 & 1.263 \\
\hline 25 & 0.50 & \multirow{2}{*}{$\begin{array}{l}\text { Coarse } \\
\text { sand }\end{array}$} & 0.710 & 9.651 & 5.244 & 7.881 & 1.838 & 0.019 & 26.278 & 1.551 \\
\hline 35 & 1.00 & & 0.500 & 8.098 & 4.661 & 6.805 & 3.112 & 16.092 & 24.245 & 3.064 \\
\hline 45 & 1.50 & \multirow{2}{*}{$\begin{array}{c}\text { Medium } \\
\text { sand }\end{array}$} & 0.350 & 5.149 & 3.232 & 7.425 & 11.945 & 20.425 & 10.787 & 10.718 \\
\hline 60 & 2.00 & & 0.250 & 5.118 & 3.745 & 18.286 & 36.934 & 28.304 & 9.980 & 37.339 \\
\hline 80 & 2.50 & \multirow{2}{*}{$\begin{array}{l}\text { Fine } \\
\text { sand }\end{array}$} & 0.177 & 4.661 & 5.148 & 10.684 & 24.558 & 10.604 & 5.841 & 26.808 \\
\hline 120 & 3.00 & & 0.125 & 4.884 & 5.006 & 5.664 & 10.045 & 4.906 & 3.863 & 10.693 \\
\hline 170 & 3.50 & \multirow{2}{*}{$\begin{array}{c}\text { Very fine } \\
\text { sand }\end{array}$} & 0.088 & 5.367 & 6.292 & 3.953 & 2.809 & 1.883 & 1.767 & 2.908 \\
\hline 230 & 4.00 & & 0.0625 & 5.103 & 3.172 & 3.421 & 1.302 & 0.205 & 0.789 & 1.213 \\
\hline 325 & 4.50 & \multirow{2}{*}{$\begin{array}{l}\text { Silt }+ \\
\text { Clay }\end{array}$} & 0.044 & 5.341 & 4.923 & 3.684 & 1.004 & 0.233 & 0.846 & 0.403 \\
\hline$<325$ & $<4.50$ & & $<0.044$ & 4.990 & 1.899 & 2.535 & 1.223 & 1.033 & 0.339 & 0.100 \\
\hline
\end{tabular}

Mean is defined as arithmetic of a series of values in a sense of arithmetic mean. Folk and Ward (1957) proposed that

$$
\mathrm{Mz}=\frac{\varphi 16+\varphi 50+\varphi 84}{3}
$$

The mean size value of the sands range from 0 $\varphi$ to $1.93 \varphi$ (i.e. coarse to medium sands). Standard deviation, also described under various names viz. 'Measure of Dispersion', Phi Mean Deviation', 'Sorting', and 'Quartile Deviation' etc. The values of standard deviation for aquifer sands vary from $0.78 \varphi$ to $2.41 \varphi$ (i.e. Moderately sorted to very poorly sorted). Skewness is the measure of symmetry around mean. The skewness values in the present study range from -0.024 to 0.34 (i.e. slightly skewed to very positively skewed) Kurtosis is a measure of peakedness and also a function of standard deviation. It measures the ratio of the sorting in the extremes of the distribution compared with the sorting in the central part and reflects the fluctuation in the velocity of the depositing medium. The value of $\mathrm{K}_{\mathrm{G}}$ more than unity is suggestive of a greater fluctuation. The aquifer sands belong to platykurtic to very leptokurtic (i.e. $\mathrm{K}_{\mathrm{G}}$ values varying from 0.78 to 1.64 ).

Folk \& Ward (1957) has successfully applied the textural characteristics in estimating aquifer properties by plotting the median diameter (D50)

Table 5. Grain size cumulative distribution (weight percentage) of aquifer sands.

\begin{tabular}{|c|c|c|c|c|c|c|c|c|c|c|}
\hline \multirow{2}{*}{$\begin{array}{l}\text { Mesh } \\
\text { No. in } \\
\text { ASTM }\end{array}$} & \multicolumn{3}{|c|}{ Size in } & \multicolumn{7}{|c|}{ Sample No. } \\
\hline & \multicolumn{2}{|c|}{$\varphi$} & $\mathbf{m m}$ & KA1 & KA2 & KA3 & KA4 & KA5 & KA6 & KA7 \\
\hline 10 & -1.00 & \multirow{3}{*}{$\begin{array}{l}\text { Very } \\
\text { coarse } \\
\text { sand }\end{array}$} & 2.00 & 19.611 & 40.925 & 12.994 & 1.634 & 0.602 & 0.467 & 1.678 \\
\hline 14 & -0.50 & & 1.410 & 31.821 & 50.746 & 22.267 & 3.376 & 1.171 & 2.044 & 3.068 \\
\hline 18 & 0.00 & & 1.000 & 41.496 & 56.602 & 29.294 & 5.056 & 16.082 & 14.894 & 4.331 \\
\hline 25 & 0.50 & \multirow{2}{*}{$\begin{array}{c}\text { Coarse } \\
\text { sand }\end{array}$} & 0.710 & 51.147 & 61.846 & 37.175 & 6.894 & 16.101 & 41.172 & 5.882 \\
\hline 35 & 1.00 & & 0.500 & 59.245 & 66.507 & 43.980 & 10.006 & 32.193 & 65.417 & 8.946 \\
\hline 45 & 1.50 & \multirow{2}{*}{$\begin{array}{l}\text { Medium } \\
\text { sand }\end{array}$} & 0.350 & 64.394 & 69.739 & 51.405 & 21.951 & 52.618 & 76.204 & 19.664 \\
\hline 60 & 2.00 & & 0.250 & 69.512 & 73.484 & 69.691 & 58.885 & 80.922 & 86.184 & 57.003 \\
\hline 80 & 2.50 & \multirow{2}{*}{$\begin{array}{l}\text { Fine } \\
\text { sand }\end{array}$} & 0.177 & 74.173 & 78.632 & 80.375 & 83.443 & 91.526 & 92.025 & 83.811 \\
\hline 120 & 3.00 & & 0.125 & 79.057 & 83.638 & 86.039 & 93.488 & 96.432 & 95.888 & 94.504 \\
\hline 170 & 3.50 & \multirow{2}{*}{$\begin{array}{c}\text { Very fine } \\
\text { sand }\end{array}$} & 0.088 & 84.424 & 89.930 & 89.992 & 96.297 & 98.315 & 97.655 & 97.412 \\
\hline 230 & 4.00 & & 0.0625 & 89.527 & 93.102 & 93.413 & 97.599 & 98.520 & 98.444 & 98.625 \\
\hline 325 & 4.50 & \multirow{2}{*}{$\begin{array}{l}\text { Silt }+ \\
\text { Clay }\end{array}$} & 0.044 & 94.868 & 98.025 & 97.097 & 98.603 & 98.753 & 99.290 & 99.028 \\
\hline$<325$ & - & & - & 99.858 & 99.924 & 99.632 & 99.826 & 99.786 & 99.629 & 99.128 \\
\hline
\end{tabular}


Table 6. Size of percentile values (in phi units) and grain size parameters (in phi units) of aquifer sands.

\begin{tabular}{|c|r|r|r|r|r|r|r|r|r|r|r|r|}
\hline $\begin{array}{c}\text { Sam- } \\
\text { ple No. }\end{array}$ & $\boldsymbol{\varphi}_{5}$ & $\boldsymbol{\varphi}_{16}$ & $\boldsymbol{\varphi}_{\mathbf{2 5}}$ & $\boldsymbol{\varphi}_{50}$ & $\boldsymbol{\varphi}_{75}$ & $\boldsymbol{\varphi}_{\mathbf{8 4}}$ & $\boldsymbol{\varphi}_{95}$ & $\begin{array}{c}\text { Me- } \\
\text { dian } \\
\text { Diam- } \\
\text { eter }\end{array}$ & $\begin{array}{c}\text { Mean } \\
\text { Size }\end{array}$ & $\begin{array}{c}\text { Stand- } \\
\text { ard } \\
\text { Devia- } \\
\text { tion }\end{array}$ & $\begin{array}{c}\text { Skew- } \\
\text { ness }\end{array}$ & $\begin{array}{c}\text { Kurto- } \\
\text { sis }\end{array}$ \\
\hline KA1 & -1.8 & -1.2 & -0.8 & 0.50 & 2.5 & 3.5 & 4.5 & 0.50 & 0.90 & 2.13 & 0.309 & 0.78 \\
\hline KA2 & -3.3 & -2.4 & -1.7 & 0.50 & 2.1 & 2.9 & 3.9 & -0.50 & 0 & 2.41 & 0.317 & 0.78 \\
\hline KA3 & -1.7 & -0.8 & -0.4 & 1.50 & 2.3 & 2.8 & 4.1 & 1.50 & 1.13 & 1.78 & -0.145 & 0.88 \\
\hline KA4 & 0.1 & 1.3 & 1.6 & 1.90 & 2.4 & 2.6 & 3.3 & 1.90 & 1.93 & 0.81 & -0.024 & 1.64 \\
\hline KA5 & -0.2 & 0.1 & 0.7 & 1.50 & 1.8 & 2.2 & 2.8 & 1.50 & 1.26 & 0.98 & -0.233 & 1.12 \\
\hline KA6 & -0.6 & 0.1 & 0.3 & 0.60 & 1.4 & 1.8 & 2.7 & 0.60 & 0.83 & 0.92 & 0.341 & 1.23 \\
\hline KA7 & 0.3 & 1.1 & 1.6 & 1.90 & 2.3 & 2.5 & 3.1 & 1.90 & 1.80 & 0.78 & -0.036 & 1.64 \\
\hline
\end{tabular}

on abscissa and the corresponding sorting factor of the grain (i.e. $D_{10} / D_{90}$ ) on ordinate in order to infer the shorting behavior of the grains, permeability, porosity and specific yield. The generalized hydrological property of the aquifer sands of the city of Varanasi is shown in the Fig. 4. Among the hydrologic properties, specific yield is of most important being the water yielding capacity of the aquifer and found directly related to textural characters of the sediments. Meinzer (1923) defined the specific yield of soil with respect to water as the ratio of the volume of water that will drain by gravity from a saturated rock to the total volume of the rock (Meinzer 1923). This ratio is usually expressed as percentage as specific yields represent the void space that will yield water to well and is effective in furnishing water supplies. It is also known as effective porosity.

Amongst the hydrologic properties specific yield is of most important being the water yielding capacity of the aquifer and found directly related to textural characters (i.e. grain size parameters) of the sediments. The size of the particle plays an important role in deciphering about the

Table 7. Mechanical analysis data and hydrologic properties of aquifer sands.

\begin{tabular}{|c|c|c|c|c|c|c|c|c|c|c|c|}
\hline $\begin{array}{l}\dot{0} \\
z \\
\stackrel{2}{a} \\
\text { : } \\
\text { ஸू }\end{array}$ & 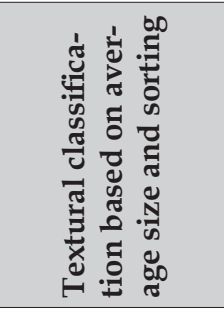 & 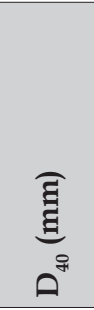 & 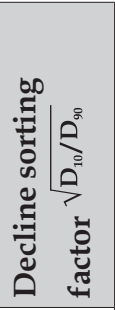 & 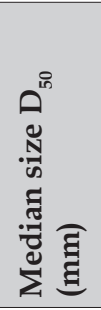 & 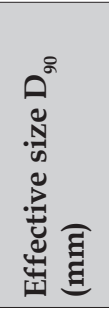 & 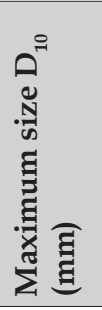 & $\begin{array}{l}0 \\
\vdots \\
\sum_{00}^{\circ} \\
0 \\
0 \\
0\end{array}$ & 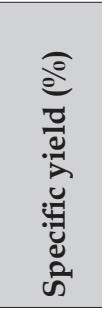 & 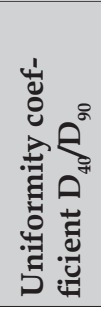 & 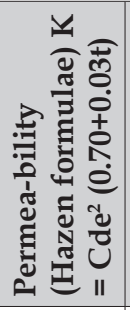 & 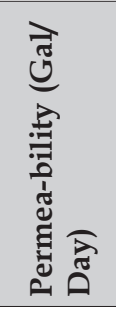 \\
\hline KA1 & $\begin{array}{l}\text { Coarse sand, } \\
\text { very poorly } \\
\text { sorted }\end{array}$ & 1.00 & 6.497 & 0.710 & 0.0625 & 2.639 & $30-40$ & $20-30$ & 16.00 & 3.303 & $10-100$ \\
\hline KA2 & $\begin{array}{l}\text { Coarse sand, } \\
\text { very poorly } \\
\text { sorted }\end{array}$ & 2.00 & 8.895 & 1.410 & 0.088 & 6.964 & $<30$ & $20-30$ & 22.72 & 6.550 & $10-100$ \\
\hline KA3 & $\begin{array}{c}\text { Medium sand, } \\
\text { poorly sorted }\end{array}$ & 0.574 & 5.289 & 0.353 & 0.088 & 2.462 & $30-40$ & $20-30$ & 6.522 & 10.917 & $10-100$ \\
\hline KA4 & $\begin{array}{c}\text { Medium sand, } \\
\text { moderately } \\
\text { sorted }\end{array}$ & 0.287 & 1.831 & 0.268 & 0.149 & 0.500 & $>40$ & $>30$ & 1.926 & 31.297 & $\begin{array}{l}100- \\
1000\end{array}$ \\
\hline KA5 & $\begin{array}{l}\text { Medium sand, } \\
\text { moderately } \\
\text { sorted }\end{array}$ & 0.406 & 2.546 & 0.353 & 0.177 & 1.148 & $30-40$ & $>30$ & 2.293 & 44.167 & $\begin{array}{l}100- \\
1000\end{array}$ \\
\hline KA6 & $\begin{array}{c}\text { Coarse sand, } \\
\text { moderately } \\
\text { sorted }\end{array}$ & 0.710 & 2.258 & 0.660 & 0.210 & 1.071 & $30-40$ & $>30$ & 3.380 & 62.172 & $\begin{array}{l}100- \\
1000\end{array}$ \\
\hline KA7 & $\begin{array}{l}\text { Medium sand, } \\
\text { moderately } \\
\text { sorted }\end{array}$ & 0.287 & 3.792 & 0.268 & 0.149 & 2.143 & $30-40$ & $20-30$ & 1.926 & 31.297 & $10-100$ \\
\hline
\end{tabular}


Table 8. Textural and Hydrological Properties of Aquifer Sands, Varanasi

\begin{tabular}{|c|c|c|c|c|c|c|c|}
\hline Sample No. & $\begin{array}{l}\text { Depth in } \\
\text { meter }\end{array}$ & $\begin{array}{l}\text { Lithology } \\
\text { Based on } \\
\text { Average } \\
\text { Size }\end{array}$ & Sorting & $\begin{array}{c}\text { Porosity } \\
\text { in } \%\end{array}$ & $\begin{array}{c}\text { Permeabil- } \\
\text { ity } \\
\text { in gpd }\end{array}$ & $\begin{array}{c}\text { Specific } \\
\text { yield } \\
\text { in } \%\end{array}$ & Remark \\
\hline KA1 & $0.0-30$ & $\begin{array}{c}\text { Coarse sands } \\
(\text { i.e. } 0.90 \varphi)\end{array}$ & $\begin{array}{c}\text { Very poorly } \\
\text { sorted (i.e. } \\
2.13 \varphi)\end{array}$ & $30-40$ & $10-100$ & $20-30$ & Poor aquifer \\
\hline KA2 & $30-40$ & $\begin{array}{l}\text { Coarse sands } \\
\text { (i.e. } 0 \varphi)\end{array}$ & $\begin{array}{c}\text { Very poorly } \\
\text { sorted (i.e. } \\
2.41 \varphi)\end{array}$ & $<30$ & $10-100$ & $20-30$ & Poor aquifer \\
\hline KA3 & $40-44$ & $\begin{array}{c}\text { Medium } \\
\text { sands (i.e. } \\
1.13 \varphi \text { ) }\end{array}$ & $\begin{array}{c}\text { Poorly sort- } \\
\text { ed }(1.78 \varphi)\end{array}$ & $30-40$ & $10-100$ & $20-30$ & Poor aquifer \\
\hline KA4 & $44-56$ & $\begin{array}{c}\text { Medium } \\
\text { sands (i.e. } \\
1.93 \varphi \text { ) }\end{array}$ & $\begin{array}{c}\text { Moderately } \\
\text { sorted (i.e. } \\
0.81 \varphi)\end{array}$ & $>40$ & $100-1000$ & $>30$ & Good aquifer \\
\hline KA5 & $56-87$ & $\begin{array}{c}\text { Medium } \\
\text { sands (i.e. } \\
1.26 \varphi \text { ) }\end{array}$ & $\begin{array}{c}\text { Moderately } \\
\text { sorted (i.e. } \\
0.98 \varphi)\end{array}$ & $30-40$ & $100-1000$ & $>30$ & $\begin{array}{l}\text { Very good } \\
\text { aquifer for } \\
\text { domestic } \\
\text { purpose }\end{array}$ \\
\hline KA6 & $87-165$ & $\begin{array}{c}\text { Coarse sands } \\
\text { (i.e. } 0.83 \varphi)\end{array}$ & $\begin{array}{c}\text { Moderately } \\
\text { sorted (i.e. } \\
0.92 \varphi)\end{array}$ & $30-40$ & $100-1000$ & $>30$ & $\begin{array}{c}\text { Potentially } \\
\text { good aquifer } \\
\text { for township } \\
\text { purpose }\end{array}$ \\
\hline KA7 & $165-175$ & $\begin{array}{c}\text { Medium } \\
\text { sands (i.e. } \\
1.80 \varphi \text { ) }\end{array}$ & $\begin{array}{c}\text { Moderately } \\
\text { sorted (i.e. } \\
0.78 \varphi \text { ) }\end{array}$ & $30-40$ & $10-100$ & $20-30$ & Poor aquifer \\
\hline
\end{tabular}

hydrologic characters of the sediments. However, the laboratory methods determine indirectly values of specific yield. In this regard, an attempt was made first by Hazen (1892), who found the relation in between the particle-size and their water retaining capacity. Of the various empirical formulae, i.e. Wenzel (1942), Brinkman (1949), Johnson (1963) and Stakman (1969), the Hazen formula (1892) is in common use. The Hazen formulae are expressed in following lines.

where,

$$
\mathrm{K}=\mathrm{Cde}^{2}{ }_{10}(0.70+0.03 \mathrm{t})
$$

$\mathrm{K}=$ Co-efficient of permeability expressed as the flow of water through a square meter of sand a day under a hydraulic gradient of hundred percent at a temperature of $50^{\circ} \mathrm{F}$. It is expressed in $\mathrm{m} / \mathrm{d}$,

$\mathrm{C}=\mathrm{a}$ constant. A value, ranging between 600 and 1000, may be chosen depending upon the uniformity co-efficient, i.e. 600 when uniformity coefficient value is higher and 1000 when it is small, de $=$ effective size of sand grain in $\mathrm{mm}$ (a size such that $10 \%$ of the material is of smaller grains and $90 \%$ of the larger grains), $\mathrm{t}=$ temperature of water in ${ }^{\circ} \mathrm{C}$. The ground water temperature is near about the mean annual atmospheric temperature.

However, a preliminary evaluation of permeability (K) \& specific yield of unconsolidated sedimentary material can be made by employing empirical methods of relating $\mathrm{K}$ with texture (Sand : Silt : Clay ratio) and some critical size parameters like effective size $\left(\mathrm{d}_{90}\right)$ and median size $\left(d_{50}\right)$. The parameters obtained after Hazen (1892) are inconsistent with pump test values in pebbly and boulder formation (Karanth 1996). Meinzer (1923) concluded that definite relation could not be drawn between particle size and their water yielding capacity. He, however, emphasized the need for more test of the same sort like those of earlier worker e.g. Hazen (1892). In the present study, porosity, permeability and specific yield have been evaluated by plotting on double log graph, the sorting factor (i.e. D10/D90) $1 / 2$ on the vertical scale and median diameter $\left(\mathrm{D}_{50}\right)$ on the horizontal scale (Fig. 4). The hydrological and textural properties of the aquifer sands are shown in the Tables 7 and 8. 


\section{Conclusions}

Ground water in the area is occurring in two distinct sedimentary horizons namely: (1) backswamp clays containing Kankar at places lying immediately below the land surface and having an average thickness of about 50 metres and (2) the underlying meander-belt deposits consisting of fine to coarse grained sands having an average thickness of about 60 metres. The back-swamp deposit supplies water to the good number of dug wells, bore well and wells fitted with small pumps used either for domestic or irrigation purposes. Whereas, the meander belt sand deposits form the main ground water body in the area and supply water to the large number of tubewells used for irrigation, industrial and domestic purposes. The ultimate source of water which sustains ground water body, in fine to coarse-grained sands of the Older Alluvium, is rainfall. The annual average precipitation (50 years average) in the city is 1076 $\mathrm{mm}$. A part of the rain that falls return to the atmosphere by evaporation, a part runs off on the surface as streams. There is no proper management of ground water recharging in the area. The southern part of the city, lying high, is most affected owing to water scarcity. Hence, a fresh water bearing zone is to be identified in the region. The analyses of the aquifer sands of this region reveal that these sands are intermixing of medium and coarse sand particles. According to sorting classification of Folk \& Ward (opacity), the sands of the area are very poorly to moderately sorted in nature. From the hydrological study of the aquifer sands, it is evident that the water bearing horizons have porosity more than 40 or $30-40 \%$ and permeability 100-1000 gpd (gallon per day) and specific yield being $>30 \%$. From the grain size analysis and hydrological study it may be concluded that water bearing zones are mainly found in three horizons at the depths (44-56 $\mathrm{m} ; 56-87 \mathrm{~m}$; 87-165 m). The first water bearing horizon at a depth $44-56 \mathrm{~m}$ is more prone to contamination. In spite of good porosity $(>40 \%)$, its shallow thickness is not favorable for providing fresh water. The second aquifer zone at a depth of $56-87 \mathrm{~m}$ (i.e. total thickness being $=31 \mathrm{~m}$ ) can act as a very good aquifer for domestic purpose owing to its good porosity (30-40\%), permeability (100-1000 gpd) and specific yield (>30\%).Where- as third water bearing horizon starts at a depth of 87-165 $\mathrm{m}$ (total thickness being $78 \mathrm{~m}$ ) can act as a good potential ground water horizon for township purpose. Due to its greater depth, the water would be relatively fresh being characterized by very low concentration of dissolved solids. Therefore, this horizon is strongly recommended for utilizing the water resource for the township which would be developed in near future by the Government under the integrated development plan of Greater Varanasi, a part of the Jawaharlal Nehru Urban Renewal Mission.

\section{Acknowledgements}

We wish to express our heartfelt thanks to Professor K.N.P. Raju, Department of Geography, Banaras Hindu University, Varanasi for his kind help in improving the text.

\section{References}

Ahmed S., Sayed M.H., Barun S., Khan M.H., Faruquee M.H. \& JALIL A., 2001. Arsenic in drinking water and pregnancy outcome. Environ Health Perspect 109: 629-631.

Ahmed S., Sengupta M.K., Mukherjee A., Hossain M.A., Das B., Nayak B., Pal A., Mukherjee S.C., Pati S., Dutta R.N., Chetterjee G., Mukherjee A., Srivastava R. \& Chakraborti D., 2006. Arsenic groundwater contamination and its health effects in the state of Uttar Pradesh in Upper and Middle Ganga Plain, India: A severe danger. Science of the Total Environment 370: 310-322.

Bhattacharya S., Chakravarty S., Maity S., Dureja V. \& GUPTA K.K., 2005. Metal contents in the groundwater of Sahebgunj district, Jharkhand, India, with special reference to arsenic. Chemosphere 58: 1203-1217.

BRINKMAN H.C., 1949. On the permeability of media consisting of closely packed porous particles. Journal Applied Sci. Res. 1: 81-86.

Chakraborti D., Mukherjee S.C., Pati S., Sengupta M.K., RahMAN M.M. \& ChAUDHARY U.K., 2003. Arsenic groundwater contamination in the Middle Ganga Plain. Bihar, India: A future danger. Environ Health Perspect. 111(9): 1194-1201.

Chakraborti D., Rahman M.M., Paul K., Chaudhary U.K., Sengupta M.K. \& LodH D., 2002. Arsenic calamity in the Indian sub-continent - what lessons have been learnt. Talanta 58: 3-22.

Chakraborti D., Sengupta M.K., Rahman M.M., Ahmed S., Chaudhary U.K. \& Hossain M.A., 2004. Groundwater arsenic contamination and its health effects in the Ganga-Meghna-Brahmaputra Plain. J. Environ Monitoring 6: $75 \mathrm{~N}-83 \mathrm{~N}$.

Chaudhary U.K., Rahman M.M., Mondal B.K., Paul K., Lodh D. \& BASU G.K., 2001. Groundwater arsenic contamina- 
tion and human suffering in the west Bengal-India and Bangladesh. Environment 8(5): 393-415.

CHOWDHARY V., GUNNAR J. \& GuSTAFSSON J.E., 2002. An analysis of groundwater vulnerability and water policy reform in India. Environmental Management and Health 13(2): 175193.

DoEgLas D.J., 1946. Interpretation of the results of mechanical analyses. Journal of Sedimentary Petrology 16(1): 19-40.

FolK R.L. \& Ward W.C., 1957.. Brazos river bar: a study in the significance of grainsize parameters. Jour. Sed. Petrol. 27: 3-26.

HAZEN A., 1892. Experiments upon the purification of sewage and water at the Lawrence, experiment station, Nol.1, 1889 to Dec., 1891. Massachusetts State Board of Health. 23rd Annual Report: 428-434.

JoHnson A.I., 1963. Application of laboratory permeability data. Open File Report. US Geological Survey of Water Resources Division, Denver, Colorado: 34.

KARANTH K.R., 1996. Use of sieve analysis data for estimation of aquifer constants. BHU - JAL News, Journal of the Central Ground Water Board, India.

KRISHNAN M.S., 1960. The Geology of India and Burma. The Associated Printers (Madras) Private Ltd., Mount Road, Madras: 555.

MeINZER O.B., 1923. Outline of ground water hydrology with definition. US Geological Survey Water Supply Paper 71: 434.

Mukherjee S.C., Saha K.C., Pati S., Dutta R.N., Rahman M.M. \& Sengupta M.K., 2005. Murshidabad-one of the nine groundwater arsenic effected districts of West Bengal, India. Part II. Dermatological, Neurological and Obstetric findings. Clin. Toxicol. 43: 835-848.

Mukherjee S.C., Rahman M.M., Chaudhary U.K., Sengupta M.K., Lodh D. \& Chanda C.R., 2003. Neuropathy in arsenic toxicity from groundwater arsenic contamination in West Bengal-India. Journal of Environmental Science Health A38(1): 165-183.

PathaK B.D., 1977. Geology and Ground water conditions of Varanasi district, U.P. Ball. Geological Survey of India, Series (B), 41.

Raha P., Singh S.K. \& BanerJee H., 2003. Organochlorine pesticide residue in groundwater in world oldest existing civilized city, Varanasi. Indian Journal of Agricultural Environment \& Biotechnology (1): 94-107.

Rahman M.M., Chaudhary U.K., Mukherjee S., Mondal B.K., Paul K. \& Lodh D., 2001. Chronic arsenic toxicity in
Bangladesh and West Bengal, India - a review and commentary. Journal of Clin. Toxicol. 39(7): 683-700.

Rahman M.M., SenguPta M.K., Ahmed S., ChOwdhury U.K., Hossain M.A. \& Das B., 2005. The magnitude of arsenic contamination in groundwater and its health effects to the inhabitants, of the Jalangi, one of the 85 arsenic affected blocks in West Bengal, India. Sci. Total Environ. 338(3): 189-200.

Rahman M.M., Sengupta M.K., Ahmed S., Chowdhury U.K., LodH D. \& Hossain M.A., 2005. A detailed study of the arsenic contamination of groundwater and its impact on residents in Rajapur village of the Domkal block, district Murshidabad, West Bengal, India. B. World Health Organ, 83(1): 49-57.

Rahman M.M., Sengupta M.K., Mukherjee S.C., Pati S., Ahmed S. \& LoDH D., 2005. Murshidabad-one of the nine groundwater arsenic affected districts of West Bengal, India. Magnitude of contamination and population at risk. Clin. Toxicol. 43: 823-834.

Rahman M.M., Mandal B.K., RoYchowdhuRY T.R., SENGUPTA M.K., Chowdhury U.K. \& LodH D., 2003 Arsenic groundwater contamination and sufferings of people in North 24-Parganas, one of the nine arsenic affected districts of West Bengal, India: the seven years study repots. Environs Sci. Health A38(1): 27-59.

Report of the 'Hindustan' a newspaper, lowering of water level of the tube wells in the city of Varanasi. April 16, 2006, 1.

Report of the 'Hindustan' Newspaper, a Hindi dailies, Ground water at an alarming stage. Feb. 27, 2006, 3.

Roychowdhury T., Basu G.K., Mandal B.K., Biswas B.K., Chowdhury U.K. \& CHAND C.K., 1999. Arsenic poisoning in the Ganges Delta. Nature 401: 545-546.

SINDOWSKI K.H., 1957. Die synoptische method des korkurven: vergleiches zur ausdeutung fossiler sedimentations raume. J. Geologisches Jahrbuch 73: 135-275.

Singh S.K., RAHA P. \& BANERJEe H., 2006. Banned organ chlorine cyclodeine pesticide in groundwater in Varanasi, India. Bulletin of Environmental Contamination and Toxicology 76: 935-941.

StAKMAn W.P., 1969. The relation between particle size, pore size and hydraulic conductivity of sand separates. Proc. Wageningen Symposium on water in the Unsaturated Zone. IASH-AISH-UNESCO: 373-384.

WeNZEL L.K., 1942. Methods of determining permeability of water bearing materials. US Geol. Surv. Water Supply Paper 887. 